\title{
ПЕДАГОГІЧНІ УМОВИ ПРОФЕСІЙНОЇ ПІДГОТОВКИ МАЙБУТНІХ ФАХІВЦІВ СФЕРИ ПОСЛУГ В УМОВАХ ОСВІТНЬО-ВИРОБНИЧОГО КЛАСТЕРУ
}

\footnotetext{
4. Жинкин Н. И. Речь как проводник информации. - М.: Наука, 1982. - 160 с.

5. Зимняя И. А. Психологические аспекты обучения говорению на иностранном языке. - М.: Просвещение, 1978. - 160 c.

6. Програма з англійської мови для професійного спілкування / Бакаєва Г. С., Борисенко О. А., Зуєнок I. I., Іваніщева В. О., Клименко Л. Й., Козимирська Т. І., Кострицька С. І., Скрипник Т. І., Тодорова Н. Ю., Ходцева А. О. - К.: Ленвіт, 2005 - 119 с.

7. Стратегія реформування освіти в Україні: рекомендації з освітньої політики. - К.: К. І. С., 2003. -296 с.
}

\section{REFERENCES}

1. Valeeva, A. F. (2003). Yazyikovoe povedenie $v$ polietnicheskom obschestve (sotsiologicheskaya diversifikativnost) [Linguistic behavior in a multiethnic society (sociological diversification)]. (Ed.). G. V. Dyilnova. Publishing house of the Saratov University, 312 p. [in Russian].

2. Vinokur, T. G. (1993). Movets i sluhach. Varianty movnoi povedinky [Speech and listener. Variations of linguistic behavior]. Moscow: Science, 172 p. [in Ukrainian].

3. Vikulina, M. A. (2001). Realizatsiya lichnostnoorientirovannogo protsessa podgotovki pedagogov [Realization of the person-oriented process of teacher training]. Novgorod: Publishing house, 153p. [in Ukrainian].

4. Zhinkin, N. I. (1982). Rech kak provodnik informatsii [Speech as a conduit of information]. Moscow: Science, 160p. [in Russian].

5. Zimnyaya, I. A. (1978). Psihologicheskie aspekty $i$ obucheniya govoreniyu na inostrannom yazyike. [Psychological aspects of learning to speak in a foreign language]. Moscow: Education, 160p.

6. Bakaeva, G. E., Borisenko, O. A., Zuenok, I. I., Ivanischeva, V. O., Klimenko, L. Y., Kozimirska, T. I. \& Kostritska, S. I. et al (2005). Programa $z$ angliyskoyi movy dlia profesiynogo spilkuvannya [English language program for professional communication]. Kyiv: Lenvit, 119p. [in Ukrainian].

7. Strategiya reformuvannya osviti v Ukrayini: rekomendatsiyi z osvitnoyi polityk (2003). [Strategy for reforming education in Ukraine: recommendations on educational policy]. Kyiv: K. I. C. 296 p. [in Ukrainian].

Стаття надійшла до редакції 02.03.2018

УДК 377.36:338.46

DOI:

Ліна Короткова, кандидат педагогічних наук, директор Державного навчального закладу "Запорізьке вище професійне училище моди і стилю”

\section{ПЕДАГОГІЧНІ УМОВИ ПРОФЕСІЙНОЇ ПІДГОТОВКИ МАЙБУТНІХ ФАХІВЦІВ СФЕРИ ПОСЛУГ В УМОВАХ ОСВІТНЬО-ВИРОБНИЧОГО КЛАСТЕРУ}

У статті розкрито сутність термінів “умови”, “педагогічні умови”, обгрунтовано сукупність педагогічних умов, які сприяють ефективному формуванню професійної компетентності майбутніх фахівців сфери послуг в умовах освітньо-виробничого кластеру: формування позитивної мотивації до оволодіння сучасними виробничими технологіями, оновлення змісту професійної підготовки майбутніх фахівців сфери послуг на основі модульно-компетентнісного підходу, застосування інноваційних педагогічних технологій, впровадження інтегративного навчально-методичного забезпечення.

Ключові слова: умови; педагогічні умови; майбутні фахівці сфери послуг; мотивація; інноваційні технологї; інтегративне навчально-методичне забезпечення.

Jim. 10.

Lina Korotkova, Ph.D.(Pedagogy), Director of the State Educational Institution "Zaporizhzhya Higher Professional School of Fashion and Style"

\section{PEDAGOGICAL CONDITIONS OF THE PROFESSIONAL TRAINING OF FUTURE SERVICE SPECIALISTS WITHIN THE FRAMEWORK OFTHE EDUCATIONAL PRODUCTION CLUSTER}

The article clarifies that the implementation of pedagogical conditions of the professional training of future service specialists within the framework of the educational production cluster will act to raise efficiency and quality of the education as well as promote the formation of highly skilled professionals. According to the research tasks, the content of the concepts "conditions" and "pedagogical conditions" has been analyzed. Pedagogical conditions of the professional training of future service specialists are determined to be the set of components of the pedagogical system, its dynamics and development, taking into account the external and internal factors and conditions.

The analysis of pedagogical conditions of the formation and development of various aspects of the future specialists' professional competence has been carried out based on the examination of modern pedagogical works. 


\section{ПЕДАГОГІЧНІ УМОВИ ПРОФЕСІЙНОЇ ПІДГОТОВКИ МАЙБУТНІХ ФАХІВЦІВ СФЕРИ ПОСЛУГ В УМОВАХ ОСВІТНЬО-ВИРОБНИЧОГО КЛАСТЕРУ}

Four basic pedagogical conditions of the professional training of future service specialists have been substantiated. The first condition is defined as "the formation of the positive motivation for mastering the modern production technologies", which orientates students to the conscious acquisition of knowledge, skills and abilities; and the individual development of the personality through self-education, self-improvement, self-discovery and self-esteem.

The second condition "updating the content of the professional training of future service specialists on the basis of the modular-competency approach" envisages the involvement of companies' representatives participants of the cluster into the adjustment and development of new initial plans and programs, taking into account the requirements of employers. The next condition for "applying innovative pedagogical technologies" envisages the introduction of the interactive learning techniques, project-oriented technologies and modularcompetency ones, which will contribute to increasing the opportunities for the qualitative professional training. The pedagogical condition for "implementing the integrative educational and methodological support" is provided by the set of educational and didactic documents, the scientific-methodical and educational literature, the technical and didactic training resources, means of control and criteria for evaluating the academic achievements of students, necessary for the formation of professional skills and abilities.

Keywords: conditions; pedagogical conditions; the future specialists in the sphere of services; motivation; the innovative technologies; integrative teaching and methodological support.

П остановка проблеми. Динамічний розвиток суспільства, підвищення рівня економічного розвитку країни, збільшення попиту на якісні соціально-культурні послуги зумовлюють стрімкий розвиток сфери послуг, що потребує оновлення системи професійної підготовки майбутніх фахівців для цієї галузі. Якість освіти сьогодні розглядається як ключовий фактор сталого розвитку країни, іiі технологічної й економічної безпеки.

3 цією метою уряд України визначив основні пріоритети своєї діяльності, серед яких: модернізація професійної освіти; налагодження тісної співпраці з соціальними партнерами; впровадження нової системи управління й фінансування науки; забезпечення економіки країни кваліфікованою конкурентоспроможною робочою силою, ефективне використання наявного трудового потенціалу, створення нових робочих місць тощо.

Підвищенню ефективності та якості освіти, формуванню висококваліфікованих професіоналів, здатних самостійно й творчо мислити сприятимуть: впровадження інноваційних педагогічних технологій; пошук нових принципів і підходів до навчального процесу; зміни у змісті, формах й методах навчання, а також сукупність об'єктивних і суб'єктивних чинників, - що складають зміст педагогічних умов професійної підготовки майбутніх фахівців сфери послуг в умовах освітньо-виробничого кластеру.

Аналіз останніх досліджень і публікацій. Аналіз педагогічної теорії та практики показав, що проблеми організації навчального процесу в професійних навчальних закладах i на виробництві, його науково-методичного забезпечення у різні часи досліджувалися С. Батишевим, Н. Кравцовим, А. Лейбовичем, О. Новіковим, О. Щербак. Актуальним питанням визначення педагогічних умов формування й розвитку різних аспектів професійної компетентності майбутніх фахівців присвячені праці багатьох вітчизняних і зарубіжних вчених, таких як А. Беляєв, Р. Гуревич, М. Кадемія, I. Козловська, Н. Кузьміна, В. Лінк, О. Пехота, П. Підкасистий, В. Радкевич, І. Соколова, В. Чобітько, Л. Шевчук та ін. В. Андреєвим, С. Висоцьким, Р. Гуровою детально розглянуто питання, що стосуються розкриття педагогічних умов у навчальному процесі.

Однак, недостатньо уваги приділено дослідженню педагогічних умов професійної підготовки майбутніх фахівців сфери послуг в умовах освітньо-виробничого кластеру.

Метою статті $\epsilon$ обгрунтування сукупності педагогічних умов, спрямованих на розвиток професійної компетентності майбутніх фахівців сфери послуг в умовах освітньо-виробничого кластеру.

Виклад основного матеріалу. Відповідно до завдань дослідження рівень професійної компетентності майбутніх фахівців сфери послуг підвищиться завдяки створенню раціональних педагогічних умов, що вимагає здійснення аналізу змісту понять “умови” та "педагогічні умови".

У психолого-педагогічній науці існує багато підходів до трактування самого терміну “умова". Академічний тлумачний словник української мови трактує умову як “необхідні обставини, що робить можливим здійснення, створення, утворення чого-небудь або сприяе чомусь; особливості реальної дійсності, при яких відбувається або здійснюється що-небудь; правила, що існують або встановлені в тій чи іншій галузі життя, діяльності, які забезпечують нормальну роботу чого-небудь; сукупність даних, положення, що лежать в основі чого-небудь" [10].

Вітчизняний науковець А. Литвин наголошуе 


\section{ПЕДАГОГІЧНІ УМОВИ ПРОФЕСІЙНОЇ ПІДГОТОВКИ МАЙБУТНІХ ФАХІВЦІВ СФЕРИ ПОСЛУГ В УМОВАХ ОСВІТНЬО-ВИРОБНИЧОГО КЛАСТЕРУ}

на необхідності усвідомлення умов як причин, чинників, засобів, що впливають на розвиток особистості [3, 65].

У словнику 3 освіти та педагогіки під редакцією В. Полонського умови визначають як сукупність перемінних природних, соціальних, зовнішніх та внугрішніх впливів, що позначаються на фізичному, психічному, моральному розвитку людини, його поведінці, вихованні і навчанні, формуванні особистості [7, 36].

У педагогіці існують різні підходи до визначення змісту поняття "педагогічні умови", які являють собою якісну характеристику основних факторів, процесів і явищ освітнього середовища 3 відповідними вимогами до організації діяльності; сукупність об'єктивних можливостей та обставин освітньої діяльності; комплекс заходів, що забезпечують розв'язання конкретного педагогічного завдання та сприяють підвищенню ефективності навчального процесу.

На думку Ю. Бабанського, “ефективність педагогічного процесу закономірно залежить від умов, у яких він здійснюється" $[1,78]$. Науковець під педагогічними умовами розуміє обставини, за яких компоненти навчання (цілі, завдання, зміст, процес, принципи, методи, засоби, організаційні форми) взаємодіють між собою та дають можливість педагогічному працівнику результативно здійснювати освітній процес, а учню - успішно вчитися.

Для нашого дослідження цікавою є думка I. Мороз, яка педагогічні умови розглядає як функціонування трисуб'єктної взаємодії “навчальний заклад - учень - роботодавець” [5, 4].

Дослідниця I. Матійків наголошує, що якість підготовки учнів професійних навчальних закладів сфери обслуговування підвищиться за умови впровадження в освітній процес науково обгрунтованої методики формування соціальнопсихологічних компетенцій; врахування специфіки професій типу “людина - людина”; визначення критеріїв і показників рівнів сформованості професійної компетентності майбутніх фахівців; урахування у системі професійної освіти прогресивних психологопедагогічних концепцій особистісного і професійного розвитку особистості $[4,5]$.

В. Радкевич для формування професійної компетентності майбутніх фахівців виділяє такі педагогічні умови: наявність висококваліфікованих педагогічних працівників; організація навчального процесу; методика викладання навчальних дисциплін; міжпредметні зв'язки; централізоване програмно-методичне забезпечення; постійно оновлюєма навчально-матеріальна база $[9,48]$.
Враховуючи радикальні зміни у ринковій економіці, впровадження інформаційнокомунікативних технологій, нових форм організації праці виникає необхідність модернізації системи професійної підготовки майбутніх фахівців, яка повинна гнучко реагувати на постійні інновації в технологіях виробництва. У ратифікованій Угоді про асоціацію між Україною та Європейським Союзом (далі - СС) передбачено підвищення ефективності системи професійної підготовки у напрямі забезпечення відповідності потребам ринку праці та стандартам $\mathrm{CC}$, що вимагає створення необхідних педагогічних умов забезпечення якісної професійної підготовки кваліфікованих робітників.

Отже, на основі вищезазначеного під педагогічними умовами професійної підготовки майбутніх фахівців сфери послуг в умовах освітньо-виробничого кластеру ми розуміємо сукупність компонентів педагогічної системи, іï динаміку й розвиток з урахуванням зовнішніх і внутрішніх факторів та умов, а саме:

- формування позитивної мотивації до оволодіння сучасними виробничими технологіями в Центрі розвитку професійної компетентності;

- оновлення змісту професійної підготовки майбутніх фахівців сфери послуг на основі компетентнісного підходу;

- застосування інноваційних педагогічних технологій;

- впровадження інтегративного навчальнометодичного забезпечення.

Визначені педагогічні умови становлять комплекс взаємопов'язаних, взаємообумовлених і взаємодоповнюючих елементів, які у тісному взаємозв'язку один 3 одним забезпечують реалізацію поставленої мети. Розглянемо сутність кожної з умов та визначимо їхнє місце у процесі формування професійної компетентності.

Першою умовою ефективної професійної підготовки майбутніх фахівців сфери послуг в умовах освітньо-професійного кластеру $є$ формування позитивної мотивації до оволодіння сучасними виробничими технологіями, яка орієнтує учнів на свідоме засвоєння знань, вмінь та навичок, індивідуальний розвиток особистості через самоосвіту, самовдосконалення, самопізнання та самооцінку.

Ряд вчених (А. Бодалев, Р. Гуревич, С. Ільїн, А. Маркова, Н. Нестерова, М. Сметанський, В. Шахов та ін.) вважають, що успішність навчальної діяльності суттєво залежить від сформованості у студентів професійної мотивації.

Необхідними умовами професійного розвитку 


\section{ПЕДАГОГІЧНІ УМОВИ ПРОФЕСІЙНОЇ ПІДГОТОВКИ МАЙБУТНІХ ФАХІВЦІВ СФЕРИ ПОСЛУГ В УМОВАХ ОСВІТНЬО-ВИРОБНИЧОГО КЛАСТЕРУ}

працівників підприємств сфери послуг, на думку В. Радкевич, є їхня зацікавленість обраною професією, яка стимулює до оволодіння новими знаннями, прийомами і способами діяльності $[8$, $27-31]$.

Основним мотивом сучасного педагогічного процесу стає досягнення успіху від ситуативного, дидактичного, при виконанні певного завдання на навчальному занятті, до професійного та матеріального у трудовій діяльності за обраною професією.

Формування позитивної мотивація полягає в інтеграції спонукань, потреб, цілей, пов'язаних 3 навчальною та професійною діяльністю 3 урахуванням різнопланових мотивів професійних та особистісних.

Мотиви професійного розвитку та кар'єрного зростання пов'язані 3 прагненням стати висококваліфікованим фахівцем, досягненням успіху в реалізації поставлених цілей, забезпеченні успішності майбутньої професійної діяльності, розвитку кар'єри та наявністю потреби влаштування на високооплачувану роботу завдяки отриманим знанням. Організація діяльності освітньо-виробничого кластеру забезпечує можливість безперервного “занурення” учнів у сферу їх майбутньої професійної діяльності, дозволяє вивчати, узагальнювати і накопичувати передовий досвід, оперативно використовувати досягнення науки і техніки, оновлювати організацію та зміст професійної підготовки. Професійна мотивація формується під час систематичного розв'язання завдань професійного спрямування; дослідження процесів, пов'язаних 3 професійною діяльністю за умови поєднання теоретичної та практичної складових процесу навчання; проходження виробничих практик в умовах реального виробництва на підприємствах, які є учасниками освітньо-виробничого кластеру.

Особистісні мотиви пов'язані з усвідомленням потреби у професійній освіті, придбанням глибоких i міцних знань, актуалізацією пізнавального інтересу, отриманням задоволення від процесу навчання, постійним інтелектуальним, духовним і особистісно-професійним зростанням. Процес формування в учнів мотивації до пізнавальної діяльності включає організацію навчального процесу 3 використанням інноваційних педагогічних технологій та інтерактивних методів, новітніх досягнень у техніці і технологіях, індивідуальних і колективних форм навчальної діяльності тощо. Для розвитку позитивної мотивації майбутніх фахівців сфери послуг використовуються методи моделювання різноманітних ситуацій професійного спрямування; застосовуються групові форми організації освітнього процесу; забезпечується оперативне та своєчасне виконання замовлень відповідно до запитів клієнтів і вимог роботодавців тощо.

Важливою умовою формування професійної компетентності майбутніх фахівців сфери послуг в умовах освітньо-професійного кластеру $є$ оновлення змісту професійної підготовки майбутніх фахівців сфери послуг на основі модульно-компетентнісного підходу.

Питаннями модернізації змісту вітчизняної освіти опікуються такі вчені як В. Андрущенко, В. Бабак, О. Коваленко та ін. Принципи, вимоги, фактори, критерії відбору змісту освіти розглядаються в працях Ю. Бабанського, Н. Волкової, О. Железнякової, М. Пєтухова, М. Фіцули та ін.

У Положенні про освітньо-кваліфікаційні рівні (ступеневу освіту) визначено, що “зміст освіти це зумовлені цілями та потребами суспільства вимоги до системи знань, умінь та навичок, світогляду та громадських і професійних якостей майбутнього фахівця, які формуються у процесі навчання $з$ урахуванням перспектив розвитку науки, техніки, технологій та культури" [6].

Для забезпечення конкурентоспроможності, мобільності, відповідності випускників навчальних закладів сфери послуг сучасним вимогам, зміст професійної освіти має постійно реагувати на зміни ринку праці, узгоджуватись та випереджати їх, що дозволить майбутнім фахівцям успішно працювати 3 новітніми матеріалами та обладнанням.

Оновлення змісту професійної підготовки в умовах освітньо-виробничого кластеру сфери послуг передбачає: здійснення аналізу ринку праці регіону 3 метою визначення потреб у кваліфікованих робітниках, рівнях їх кваліфікації й компетентності; залучення представників підприємств - учасників кластеру до участі у державних кваліфікаційних атестаціях; проведення спільно з ними засідань методичних комісій закладів освіти по виявленню нових перспективних інтегрованих професій, видів робіт, враховуючи появу нових матеріалів та технологій; проведення стажування педагогічних працівників та виробничої практики учнів на провідних підприємствах сфери послуг; коригування та розроблення нових начальних планів i програм на основі модульнокомпетентнісного підходу з урахуванням вимог роботодавців.

Для досягнення якісних результатів професійної підготовки майбутніх фахівців сфери послуг 


\section{ПЕДАГОГІЧНІ УМОВИ ПРОФЕСІЙНОЇ ПДГОТОВКИ МАЙБУТНІХ ФАХІВЦІВ СФЕРИ ПОСЛУГ В УМОВАХ ОСВІТНЬО-ВИРОБНИЧОГО КЛАСТЕРУ}

важливою педагогічною умовою є застосування інноваційних педагогічних технологій.

Сучасні вимоги до підготовки робітничих кадрів вимагають здійснення пошуку та впровадження у освітній процес інноваційних педагогічних технологій, які спрямовані на задоволення актуальних проблем системи освіти, спираючись на використанні нових знань.

В рамках освітньо-виробничого кластеру, організація та принципи діяльності якого дозволяють ефективніше використовувати й поєднувати різноманітні інноваційні технології професійного навчання, відпрацьовуються нові педагогічні та наукові ідеї, визначається їхня ефективність. Відбір педагогічних технологій відбувається 3 орієнтацією на розвиток пізнавально-трудової активності, професійної мобільності, самовизначення, оволодіння спеціальними знаннями, вміннями, методами і засобами відповідної професійної сфери. Для підвищення якості професійної підготовки майбутніх фахівців сфери послуг педагогічні працівники активно застосовують технології інтерактивного навчання (здійснення освітнього процесу за умови постійної активної взаємодії усіх його учасників); проектні технології (стимулювання інтересу учнів до здобуття нових знань, умінь і навичок через участь у проектній діяльності); модульно-компетентнісну технологію (адаптація процесу навчання до індивідуальних запитів та рівня підготовленості майбутніх фахівців, створення індивідуальної траєкторії навчання, концентрація на кінцевих результатах). Застосування інноваційних технологій професійної підготовки майбутніх фахівців сфери послуг в умовах освітньо-виробничого кластеру розкриває можливості для формування творчої особистості, сприяє розвитку інтелектуальних здібностей, самостійності, відповідальності, уміння планувати, приймати рішення, проявляти ініціативу, що сприяє збільшенню можливостей для якісної професійної підготовки.

Наступною педагогічною умовою визначено впровадження інтегративного навчальнометодичного забезпечення.

Педагогічна інтеграція є доцільно організованим зв'язком однотипних частин і елементів змісту, форм і методів навчання в рамках освітньої системи, що веде до саморозвитку особистості. Проблема інтеграції в різних її аспектах досліджується багатьма науковцями, зокрема Г. Білецькою, О. Вознюком, К. Волинець, Т. Волковою, С. Гончаренком, О. Логіновою, Т. Мантули, Л. Сліпчишиним, Р. Собко та ін.

Навчально-методичне забезпечення професійного навчання передбачає оптимальну систему навчально-дидактичної документації, науковометодичної та навчальної літератури, технічних і дидактичних засобів навчання, засобів контролю та критеріїв оцінювання навчальних досягнень учнів, необхідних для формування професійних умінь i навичок відповідно до вимог кваліфікаційних характеристик $[2,13]$.

До основних дидактичних засобів навчання майбутніх фахівців сфери послуг нами віднесено: освітній стандарт на модульно-компетентнісній основі; інтегровані робочі навчальні плани та програми, на основі яких здійснюється тематичне поєднання поурочного змісту споріднених профільних предметів (наприклад, для професії “Кравець. Закрійник” - “Технологія виготовлення одягу”, “Основи конструювання одягу”, “Матеріалознавство”, “Обладнання швейного виробництва” та виробниче навчання); інструктивнометодичні посібники для учнів, викладачів і майстрів виробничого навчання; комплексні тестові й кваліфікаційні завдання, критерії оцінювання навчальних досягнень учнів тощо.

Отже, реалізація педагогічних умов професійної підготовки майбутніх фахівців сфери послуг сприятиме формуванню висококваліфікованих робітників відповідного рівня та профілю, конкурентоспроможних на ринку праці, орієнтованих в суміжних сферах діяльності, готових до постійного росту, соціальної та професійної мобільності.

\section{ЛІТЕРАТУРА}

1. Бабанский Ю. К. Оптимизация учебновоспитательного процесса. Методические основы. М.: педагогика, 2005. 193 с.

2. Беляева А. П. Интегративно-модульная педагогическая система профессионального образования: Монография. - С.-Петербург: Радом; Институт профтехобразования РАО, 1997. 227 с.

3. Литвин А. И. Педагогічні умови інформатизації навчально-виховного процесу в ПТНЗ будівельного профілю. Педагогіка і психологія професійної освіти. 2010. № 5. С. 65-78.

4. Матійків І. М. Психологічні умови формування професійної компетентності учнів професійнотехнічних навчальних закладів сфери обслуговування: дис. ... канд. психол. наук: 19.00.07 / Прикарпат. нац. ун-т імені Василя Стефаника. Івано-Франківськ, 2008. 240 с.

5. Мороз I. В. Педагогічні умови застосування кредитно-модульної системи навчання студентів економічних факультетів ВНЗ: автореф. дис. ... канд. пед. наук: 13.00 .04 / - ЖДУ ім. I. Франка. Житомир, 2004. 20 с. 


\section{ПЕДАГОГІЧНІ УМОВИ ПРОФЕСІЙНОЇ ПІДГОТОВКИ МАЙБУТНІХ ФАХІВЦІВ СФЕРИ ПОСЛУГ В УМОВАХ ОСВІТНЬО-ВИРОБНИЧОГО КЛАСТЕРУ}

6. Положення про освітньо-кваліфікаційні рівні (ступеневу освіту). [Електронний ресурс]: Постанова КМ України від 20.01.1998 р. № 65URL: http://zakon2.rada.gov.ua/laws/show/6598-\%D0\%BF (дата звернення: 06.02.2018).

7. Полонский В. М. Словарь по образованию и педагогике. М.: Высш. шк., 2004. 512 с.

8. Радкевич В. О. Сучасні чинники розвитку професійного навчання в умовах виробництва. Професійне навчання на виробництв: зб.наук.пр. Київ, 2011. Вип.4. С. 18-27.

9. Радкевич В. О. Проблеми професійного навчання на виробництві. Професійне навчання на виробництві: зб. наук. пр. Київ, 2003. Вип. 1. С. $46-53$.

10. Словник української мови. Академічний тлумачний словник (1970-1980) [Електронний pecypc]. URL: http://sum.in.ua (дата звернення: 05.02.2018).

\section{REFERECES}

1. Babanskiy, Yu. K. (2005). Optimizatsiya uchebno-vospitatelnogo protsessa. Metodicheskiye osnovy [Optimization of teaching and educational process. Methodological fundamentals]. Moscov, 193 p. [in Russian].

2. Belyayeva, A. P. (1997). Integrativnomodulnaya pedagogicheskaya sistema professionalnogo obrazovaniya: Monografiya [Integrative-module pedagogical vocational training system: Monograph]. Saint Peterburg, 227 p. [in Russian].

3. Lytvyn, A. Y. (2010). Pedahohichni umovy informatyzatsiyi navchalno-vykhovnoho protsesu $\mathrm{V}$ PTNZ budivelnoho profilyu [Pedagogical conditions for informatization of teaching and educational process at vocational schools professionally-oriented in construction.]. Pedagogy and psychology of professional education, no. 5, pp. 65-78. [in. Ukrainian].
4. Matiykiv, I. M. (2008). Psykholohichni umovy formuvannya profesiynoyi kompetentnosti uchniv profesiyno-tekhnichnykh navchalnykh zakladiv sfery obsluhovuvannya [Psychological conditions for formation of professional competence of pupils of vocational schools of services sector]. Candidate's thesis. Ivano-Frankivsk, 240 p. [in. Ukrainian].

5. Moroz, I. V. (2004). Pedahohichni umovy zastosuvannya kredytno-modulnoyi systemy navchannya studentiv ekonomichnykh fakultetiv VNZ [Pedagogical conditions of usage of credit based modular learning for students of faculties of economics of higher education institutes]. Extended abstract of candidate's thesis. Zhytomyr, 20 p. [in. Ukrainian].

6. Polozhennya pro osvitno-kvalifikatsiyni rivni (stupenevu osvitu) (Postanova KM Ukrayiny vid 20.01.1998 r. № 65) [Regulations on education and qualification level (graded education) (Resolution of the Cabinet of Ministers of Ukraine from 20.01/ 1998 №65)]. Available at: http://zakon2.rada.gov.ua/ laws/show/65-98. [in. Ukrainian].

7. Polonskiy, V. M. (2004). Slovar po obrazovaniyu i pedagogike [Dictionary of education and pedagogics]. Moscov, 512 p. [in Russian].

8. Radkevych, V. O. (2011). Suchasni chynnyky rozvytku profesiynoho navchannya $\mathrm{v}$ umovakh vyrobnytstva [Modern evolution factors of professional shop training]. Professional training in production: sciences works. Kyiv, vol. 4, pp. 18-27. [in. Ukrainian].

9. Radkevych, V. O. (2003). Problemy profesiynoho navchannya na vyrobnytstvi [Problems of professional shop training]. Professional training in production: sciences works. Kyiv, vol. 1, pp. 46-53. [in. Ukrainian].

10. Slovnyk ukrayinskoyi movy. Akademichnyy tlumachnyy slovnyk (1970-1980) [Dictionary of the Ukrainian language. Academic definition dictionary]. Available at: http://sum.in.ua. [in. Ukrainian].

Стаття надійшла до редакції 28.02.2018

\section{G5}

“Світ відчинає двері перед тим, хто знає, куди йде”.

$$
\begin{array}{r}
\text { Ральф Волдо Емерсон } \\
\text { америқансьқий есеїст, поет і білософб }
\end{array}
$$

"Ви зможете все, чого захочете, тільқи почніть. Сміливість породжує геніальність. Точинайте негайно".

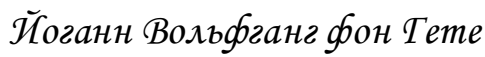
німеиький поет, прозайк, драматург

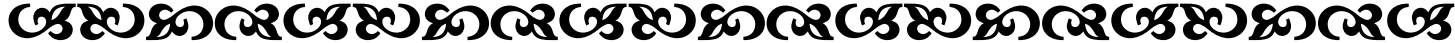

